\title{
Medical and Chemical Expertise in English Trials for Criminal Poisoning, 1750-1914
}

\author{
KATHERINE D WATSON*
}

This article contributes to the literature on the history of medico-legal practice by using a survey of 535 poisoning cases to examine the emergence of forensic toxicological expertise in nineteenth-century English criminal trials. In emphasizing chemical expertise, it seeks both to expand upon a limited literature on the history of the subject, ${ }^{1}$ and to offer a contrast to studies of criminal poisoning that have tended to focus primarily on medical expertise. ${ }^{2}$ Poisoning itself is a topic of abiding interest to historians of forensic medicine and science because (together with insanity) it long tended to attract the greatest attention (and often confrontation) in criminal proceedings. ${ }^{3}$ In looking at a wide number of cases, however, it becomes apparent that few aroused true medico-legal controversy. Rather, the evidence from several hundred cases tried as felonies during the eighteenth and nineteenth centuries indicates that prior to the 1830s few presented any opportunity for "a battle of experts". 4 While Ian Burney and Tal Golan have shown that this was certainly not the case during the mid and late nineteenth century, ${ }^{5}$ this paper goes further by dividing the period under study into three distinct phases in order to show how expert testimony (and experts themselves) changed during the course of the century, and why this process opened a door to the potential for formalized controversy.

The article is based on a database of over five hundred cases of criminal poisoning tried in England and Wales between 1750 and 1914. The survey data has been reported in my book, Poisoned lives: English poisoners and their victims, a social history of poisoning crimes focusing especially on accused poisoners, their victims, motives, the poisons used,

(C) Katherine D Watson 2006

Katherine D Watson, DPhil, School of Arts and Humanities, Oxford Brookes University, Gipsy Lane, Oxford, OX3 0BP; e-mail: kwatson@brookes.ac.uk

I am grateful for the very helpful comments and suggestions made by Steve King, John Stewart and two anonymous referees. I would like to thank Martin Sheppard for permission to reproduce material previously published by Hambledon \& London. Support for some of the research presented in this article was provided by the Centre for Health, Medicine and Society: Past and Present, Oxford Brookes University.

\footnotetext{
${ }^{1}$ M A Green, 'Dr Scattergood's case books: a 19th century medico-legal record', The Practitioner, 1973, 211: 679-84; N G Coley, 'Alfred Swaine Taylor, MD, FRS (1806-1880): forensic toxicologist', Med. Hist., 1991, 35: 409-27; N G Coley, 'Forensic chemistry in 19th-century Britain', Endeavour, 1998, 22: 143-7.

${ }^{2} \mathrm{~T}$ R Forbes, Surgeons at the Bailey: English forensic medicine to 1878, New Haven and London,
}

Yale University Press, 1985, pp. 123-65; I A Burney, 'A poisoning of no substance: the trials of medico-legal proof in mid-Victorian England', J. Br. Stud., 1999, 38: 59-92; I A Burney, 'Testing testimony: toxicology and the law of evidence in early nineteenth-century England', Stud. Hist. Philos. Sci., 2002, 33: 289-314.

${ }^{3} \mathrm{~T}$ Golan, Laws of men and laws of nature: the history of scientific expert testimony in England and America, Cambridge, MA, and London, Harvard University Press, 2004, p. 97.

${ }^{4}$ The phrase is from S Landsman, 'One hundred years of rectitude: medical witnesses at the Old Bailey, 1717-1817', Law and History Review, 1998, 16: 445-94, p. 452.

${ }^{5}$ Burney, 'A poisoning of no substance' and 'Testing testimony', op. cit., note 2 above; Golan, op. cit., note 3 above. Victorian and Edwardian England witnessed several deeply contentious cases, particularly those of Dr William Palmer, Thomas Smethurst, Florence Bravo, Adelaide Bartlett, Florence Maybrick, Dr Hawley Crippen and Frederick Seddon. 


\section{Katherine D Watson}

investigative techniques, and how all these changed over time. ${ }^{6}$ While the current study makes use of the same material, its focus on "expertise" allows a number of new points to be made, especially in regard to how medico-scientific evidence entered into trials for criminal poisoning, who presented that evidence, and how this relates more generally to the history of medicine. Studies of the Scottish system of medical police have highlighted the formal links between medicine and the law in that country, ${ }^{7}$ but such associations remain an under researched area of medical-historical enquiry. Although we are accustomed to the idea (encouraged by books and television dramas) that pathologists play a key role in solving crime, during the period under discussion pathology was in its infancy and other scientists, often chemists, were integral to the resolution of the particular crime of poisoning. The following examples are suggestive of how this process worked in early English practice.

On Friday 10 August 1821, three people were tried for murder at the summer assizes in Essex and in Yorkshire. At Chelmsford, two men were convicted of murdering women they had made pregnant; in York, a woman was convicted of the murder of her husband. All three were sentenced to death and hanged three days later, the very day on which reports of their trials appeared in The Times. ${ }^{8}$

Two of these cases involved poison. In Essex, James Emery had given his pregnant lover twelve poisonous pills, hoping to cause a miscarriage. Evidence that her death was due to arsenic was given by "Mr Tomkin, a surgeon, and Mr Baker, an operative chymist". 9 In Yorkshire, the court accepted that Ann Barber's husband James had also died from arsenic poisoning, a fact to which the surgeon and apothecary John Hindle testified. He was firm in his conclusions, but was forced to admit that although he had made certain tests for arsenic, it was the first time he had done so. According to the newspaper report, he stated that " $\mathrm{Mr}$ Postuett, a medical person was also present" when the autopsy and chemical tests were performed. ${ }^{10}$ The two correspondents, almost certainly reflecting the progress of the trials themselves, did not linger on the evidence of poisoning, being far more concerned by the motives of the two accused and the details of their private lives. If these reports can be taken as accurate reflections of the issues that most concerned the court, then it would appear that the medical and scientific evidence of poisoning was not contentious. There was no clash of opinion, legal or medical, or difficulty in convincing the jurors that death was due to arsenic poisoning. Although Ann Barber had a barrister, his cross-examination of Hindle was based on a brief he received on the morning the trial began. James Emery had no lawyer.

These cases are of interest for two reasons. Firstly, they are probably not untypical of practice in English poisoning trials during the eighteenth and much of the nineteenth century. Secondly, they give us the identities of the medical witnesses and, in the Barber case, a description of the chemical tests used. In Essex, the Mr Baker referred to in The Times was to appear in another poison trial four years later, again referred to very briefly as

\footnotetext{
${ }^{6} \mathrm{~K}$ Watson, Poisoned lives: English poisoners and their victims, London and New York, Hambledon \& London, 2004. Cases of animal poisoning have been left out of the current analysis, and several new trials added.

${ }^{7} \mathrm{M}$ A Crowther and B White, On soul and conscience. The medical expert and crime: 150 years of forensic medicine in Glasgow, Aberdeen University
}

Press, 1988; B White, 'Training medical policemen: forensic medicine and public health in nineteenthcentury Scotland', in M Clark and C Crawford (eds), Legal medicine in history, Cambridge University Press, 1994, pp. 145-63.

${ }^{8}$ The Times, 13 Aug. 1821, p. 3c.

${ }^{9}$ Ibid.

${ }^{10}$ Ibid., p. 3d. 


\section{Medical and Chemical Expertise in English Trials, 1750-1914}

"Mr W Baker, chemist of Chelmsford", ${ }^{11}$ while the "Mr Postuett" who failed to appear in court during the Barber trial was in fact Mark Edward Poskitt, a surgeon-apothecary who had first appeared as a witness in a poison trial that took place at York in August 1816 and whose presence during the autopsy on James Barber is confirmed by the depositions taken before the local coroner. ${ }^{12}$ At the time he testified at the trial of Elizabeth Ward for the attempted murder of her sister-in-law, Poskitt had had no prior experience of arsenic poisoning. He had never treated a victim of poison, or performed an autopsy on one; he had formed his opinion on the subject purely from books. But he became involved because he was the family doctor and, realizing his limitations, sought corroboration of his findings from a York chemist named John Sutcliffe. ${ }^{13}$ Given that both the Ward and Barber cases took place in Rothwell, a Yorkshire town of several thousand inhabitants, and that Ward's fate became something of a local cause célèbre, ${ }^{14}$ it would seem reasonable to suppose that although Poskitt's involvement in the earlier case was wholly accidental, he was deliberately sought out by the coroner in the second.

The hitherto unknown medico-legal "careers" of Baker and Poskitt serve as an introduction to this study of the medical and scientific men who gave evidence in cases of criminal poisoning in England and Wales between 1750 and the First World War. Who were these men? To what extent could they be considered to be experts? How did their professional profile change over time? In answering this last question, it is clear that there were three periods of development, each of which corresponded to the appearance of a particular type of witness in trials for criminal poisoning: local surgeon-apothecaries were superseded by professional (mainly academic) chemists and toxicologists, who in turn gave way when the new role of the public analyst was created in the 1870 s. The very nature of the crime of poisoning meant that both medical and chemical evidence were required to prove it, but throughout much of the period it was the chemists, not the medical men, who had distinctive career patterns and who could lay claim to a specialist body of knowledge.

\section{The Expert Witness in History}

The term "expert witness" has a long history, and is today defined in much the same way as it was at the end of the eighteenth century, when it first came into use. An expert witness is one who, in a court of law, is permitted to give evidence of both facts and opinion, to help judges and juries come to accurate decisions. This is very different from other witnesses, who give evidence solely about the facts of which they have direct knowledge. Further, the term is associated for the most part with science and medicine, and it was in a scientific context that it arose. However, the historiography of its development focuses on different aspects of its evolution. Historians of science, and some legal historians, have been concerned to show that current misgivings about the partisan nature of scientific expert testimony is far from new, having a history that stretches back at least two centuries. ${ }^{15}$

\footnotetext{
${ }^{11}$ The Times, 12 Oct. 1825 , p. $3 \mathrm{c}$.

${ }^{12}$ The National Archives: Public Record Office (hereafter PRO), ASSI 45/54, 'Yorkshire 4 Aug. 1821-The King against Ann Barber, petit treason'.

${ }^{13}$ PRO, ASSI 45/49 (Yorkshire), no title [depositions against Elizabeth Ward]; The Times, 15 Aug. 1816, p. 3b.
}

\footnotetext{
${ }^{14}$ Found guilty and sentenced to death, her execution was twice postponed; in September 1816 she was granted a pardon by the Prince Regent, see Watson, op. cit., note 6 above, pp. 175-9.

${ }^{15}$ Landsman, op. cit., note 4 above; Golan, op. cit., note 3 above; C Hamlin, 'Scientific method and expert witnessing: Victorian perspectives on a modern
} 


\section{Katherine D Watson}

Historians of medicine, on the other hand, are interested in the role played by medical men in the legal process, ${ }^{16}$ as representative of historical trends concerning professional authority in and service to society. ${ }^{17}$ The inquest has been identified as a crucial theatre in which to explore the rise of forensic medicine in England.

The concept of an expert witness arose as a result of a procedure used mainly in civil cases, when people with special expertise were appointed as advisers to the court, or to serve on special juries. Originally they did not appear on the witness stand, but during the seventeenth century they began to be called into court to present their testimony before a lay jury. Many of these possessors of specialist knowledge were asked to give advice on technical questions. ${ }^{18}$ Another important development occurred at about the same time. Until the seventeenth century, English criminal trials were almost entirely lawyer-free, being primarily a direct confrontation between the accuser and the accused. When there was any investigation to be done, it was conducted by justices of the peace. But the scandal of perjured testimony during a series of treason trials in the last quarter of the century led to significant changes in practice, ${ }^{19}$ most notably the introduction of defence council into treason trials and then, by the 1730 s, the extension of the same benefit to felony trials. This set the stage for the adversarial criminal trial that we know today, a system which was firmly in place by the end of the eighteenth century and which modern legal scholars hold to blame for the partisanship which now infects criminal trials and expert witnessing. ${ }^{20}$

As legal practice was evolving, the role played by medicine in legal matters was growing. Although coroners were justifiably criticized as lax and inefficient during the eighteenth and nineteenth centuries, and often took the view that there could be no need for medical evidence unless there were obvious signs of violence on a corpse, there were some circumstances in which coroners regularly sought medical testimony. Mark Jackson has shown this to be so in cases of newborn-child murder, following the influence of the statute of 1624 which created a legal presumption that a woman who had concealed the death of her bastard child had murdered it. ${ }^{21}$ The court needed to know whether such children had been born dead or not, and this need created space for medical testimony at inquests and

problem', Soc. Stud. Sci., 1986, 16: 485-513; C A G Jones, Expert witnesses: science, medicine, and the practice of law, Oxford, Clarendon Press, 1994;

T Golan, 'The history of scientific expert testimony in the English courtroom', Science in Context, 1999, 12: 7-32; J H Langbein, The origins of adversary criminal trial, Oxford University Press, 2003.

${ }^{16}$ Forbes, op. cit., note 2 above; Clark and Crawford (eds), op. cit., note 7 above; R Smith, Trial by medicine: insanity and responsibility in Victorian trials, Edinburgh University Press, 1981; J C Mohr, Doctors and the law: medical jurisprudence in nineteenthcentury America, New York and Oxford, Oxford University Press, 1993; J P Eigen, Witnessing insanity. madness and mad-doctors in the English court, New Haven and London, Yale University Press, 1995; $\mathrm{J}$ P Eigen, Unconscious crime: mental absence and criminal responsibility in Victorian London, Baltimore and London, Johns Hopkins University Press, 2003.
${ }^{17} \mathrm{C}$ J Crawford, 'The emergence of English forensic medicine: medical evidence in common-law courts, 1730-1830', DPhil thesis, Oxford University, 1987; R Smith and B Wynne (eds), Expert evidence: interpreting science in the law, London, Routledge, 1989; M Clark and C Crawford, 'Introduction', in Clark and Crawford (eds), op. cit., note 7 above, pp. 1-21, on p. 17; I A Burney, Bodies of evidence: medicine and the politics of the English inquest, 1830-1926, Baltimore and London, Johns Hopkins University Press, 2000.

${ }^{18}$ Landsman, op. cit., note 4 above, pp. 446-7; Golan, op. cit., note 3 above, pp. 18-22.

${ }^{19}$ Langbein, op. cit., note 15 above, pp. 67-105.

${ }^{20}$ Ibid., pp. 8-9; M Redmayne, Expert evidence and criminal justice, Oxford University Press, 2001, pp. 198-220.

${ }^{21}$ An Act to prevent the Destroying and Murthering of Bastard Children, passed in May 1624. 


\section{Medical and Chemical Expertise in English Trials, 1750-1914}

subsequent trials. By the late eighteenth century the lung test was taken by lawyers to be an example of a form of proof by experts. ${ }^{22}$

Where other types of suspicious death are concerned, there is far less evidence for the regular use of autopsy before the middle of the eighteenth century. In earlier cases of suspected poisoning in the north-west, no tests or post-mortems were performed, as clinical evidence was generally thought sufficient. ${ }^{23}$ However, there were clearly exceptions in some parts of the country, as an example of such an autopsy was recorded at Newcastle in 1662. ${ }^{24}$ Generally, though, detailed evidence by a number of skilled medical men was provided only in murder cases that had aroused wide public or political interest, ${ }^{25}$ as for example at the murder trial of the Earl of Pembroke in April 1678, ${ }^{26}$ in the murder of Sir Edmund Berry Godfrey six months later, ${ }^{27}$ and in the 1699 trial of a well-connected young lawyer, Spencer Cowper, for the alleged murder of a Quaker girl, where a group of prominent London physicians and surgeons were called in to testify for the defence. ${ }^{28}$ The Cowper case appears to be one of the earliest occasions on which medical men were allowed to give opinion evidence on behalf of the defence in a criminal trial, and to be a very early example of the potentially partisan nature of such expert testimony.

Thus, when the concept of an expert witness came formally into being, it merely gave an official name to a practice that dated back a century or more. Legal texts cite the 1782 case of Folkes v. Chadd as the precedent for the acceptance of expert opinion testimony. This civil action, which concerned the decay of a harbour in Norfolk, led the chief justice, Lord Mansfield, to conclude that the opinion of scientific men upon proven facts may be given by men of science within their own science. ${ }^{29}$ Such individuals have been described as "expert witnesses" ever since: the first explicit discussion in a legal text was published in 1791 , noting that they were a growing class of witness whose personal opinions on medical and scientific matters were, exceptionally, of evidential value to the court. ${ }^{30}$ This decision, along with the increasing use of lawyers in criminal trials, led to a shift in position: experts were no longer impartial advisers, but hired consultants dependent on the side which

\footnotetext{
${ }^{22}$ M Jackson, 'Suspicious infant deaths: the statute of 1624 and medical evidence at coroners' inquests', in Clark and Crawford (eds), op. cit., note 7 above, pp. 64-86, on p. 67; M Jackson, New-born child murder: women, illegitimacy and the courts in eighteenth-century England, Manchester University Press, 1996, pp. 84-109 (see pp. 93-100 for the intense controversy that the hydrostatic lung test provoked in medico-legal writing).

${ }^{23} \mathrm{D}$ Harley, 'The scope of legal medicine in Lancashire and Cheshire, 1660-1760', in Clark and Crawford (eds), op. cit., note 7 above, pp. 45-63, on p. 56.

${ }^{24} \mathrm{~V}$ McMahon, Murder in Shakespeare's England, London and New York, Hambledon \& London, 2004, p. 123.

${ }^{25}$ D Harley, 'Political post-mortems and morbid anatomy in seventeenth-century England', Soc. Hist. Med., 1994, 7: 1-28.
}

\footnotetext{
${ }^{26}$ Ibid., pp. 22-23; Forbes, op. cit., note 2 above, pp. 46-7.

${ }^{27}$ S Knight, The killing of Justice Godfrey, London, Grafton Books, 1986, pp. 127-9; A Marshall, The strange death of Edmund Godfrey: plots and politics in Restoration London, Stroud, Sutton Publishing, 1999, pp. 108-10, 147-51.

${ }^{28}$ A Rosenberg, 'The Sarah Stout murder case: an early example of the doctor as an expert witness', in C R Burns (ed.), Legacies in law and medicine, New York, Science History Publications, 1977, pp. 230-9; J D J Havard, The detection of secret homicide, London, Macmillan, 1960, pp. 4, 37.

${ }^{29}$ Golan, op. cit., note 3 above, pp. 22-51, especially pp. 44-5.

${ }^{30}$ Ibid., pp. 52-54; Sir Geoffrey Gilbert, The law of evidence, considerably enlarged by Capel Lofft, 4 vols, London, A Strahan and W Woodfall, 1791, vol. 1, pp. 298-302.
} 


\section{Katherine D Watson}

engaged their services. ${ }^{31}$ Numerous studies have shown that the growth of industrial society gave doctors and scientists a highly profitable market for their expertise, and that in civil cases the "hired gun" analogy was frequently accurate. ${ }^{32}$

Criminal poisoning fitted neatly into this area of overlap between science, medicine and the law because of the clear difficulties that proving a crime that was so often hidden from view (or presumptive) posed to a legal system that desired certainty. An increasingly demanding burden of proof, grounded in evolving rules of evidence, placed more and more emphasis on what legal commentators referred to generally as the "medical testimony" in cases of suspected poisoning, so that by the early nineteenth century such crimes occupied an important place in many treatises on evidence, through explicit references to poisoning in discussions of opinion evidence and the role of experts. ${ }^{33}$

\section{Medical and Chemical Expertise in Poisoning Cases}

During the eighteenth century, murder, rape, infanticide and poisoning crimes offered medical men a clear route into the courtroom, nearly always on behalf of the prosecution. It was only when defendants claimed insanity, or when they had enough money to pay for a medical man to refute the prosecution case, that doctors were brought in by the defence. But poisoning crimes as a whole have not received much attention from historians (or historians of medicine). Those who do study them tend to do so as part of a wider focus, and thus limit their analysis to a few cases, usually those which were so controversial that they resulted in immense press attention. ${ }^{34}$ Studies of early forensic medicine have pointed out that no other form of homicide offered a greater challenge to the medical practitioner, but have concentrated on trials that took place at the Old Bailey, or which were otherwise well documented because of their notoriety. ${ }^{35}$

In his work on the nineteenth century, Ian Burney has focused on scientific disagreements in cases of poisoning, looking especially at the storm that surrounded the trial of William Palmer in 1856, the first in which the alleged poison was strychnine but where the prosecution's chief witness was unable to identify it in the victim's body. ${ }^{36}$ Burney's

\footnotetext{
${ }^{31}$ Golan, op. cit., note 15 above, pp. 14-15, 26; Jones, op. cit., note 15 above, pp. 57-60.

${ }^{32}$ See, for example, J Z Fullmer, 'Technology, chemistry, and the law in early 19th-century England', Technology and Culture, 1980, 21: 1-28; M A Crowther and B M White, 'Medicine, property and the law in Britain 1800-1914', Hist. J., 1988, 31: 853-70; K D Watson, 'The chemist as expert: the consulting career of Sir William Ramsay', Ambix, 1995, 42: 143-59; Golan, op. cit., note 3 above, pp. 54-106.

${ }^{33}$ Gilbert, op. cit., note 30 above, p. 302; Landsman, op. cit., note 4 above, pp. 491-4; Burney, 'Testing testimony', op. cit., note 2 above, pp. 292-8.

${ }^{34} \mathrm{M}$ Harris, 'Social diseases? Crime and medicine in the Victorian press', in W F Bynum, S Lock and $\mathrm{R}$ Porter (eds), Medical journals and medical knowledge: historical essays, London, Routledge, 1992, pp. 108-25; A McLaren, A prescription for murder: the Victorian serial killings of Dr Thomas Neill
}

Cream, Chicago and London, University of Chicago Press, 1993; J Knelman, Twisting in the wind: the murderess and the English press, University of Toronto Press, 1998; J P Eigen, 'Sense and sensibility: fateful splitting in the Victorian insanity trial', in R A Melikan (ed.), Domestic and international trials, 1700-2000, Manchester University Press, 2003, pp. 21-35;

$\mathrm{T}$ Ward, 'A mania for suspicion: poisoning, science, and the law', in J Rowbotham and K Stevenson (eds), Criminal conversations: Victorian crimes, social panic and moral outrage, Columbus, Ohio State University Press, 2005, pp. 140-56.

${ }^{35}$ Landsman, op. cit., note 4 above, pp. 463-4, 493; Forbes, op. cit., note 2 above, pp. 123-65; C Crawford, 'Legalizing medicine: early modern legal systems and the growth of medico-legal knowledge', in Clark and Crawford (eds), op. cit., note 7 above, pp. 89-116, on pp. 106-7.

${ }^{36}$ Burney, 'A poisoning of no substance', op. cit., note 2 above. 


\section{Medical and Chemical Expertise in English Trials, 1750-1914}

interest lies in the social construction of expert evidence, and thus draws heavily on the published works of legal and medico-legal practitioners and commentators. He first identifies controversy, and then shows how it could be resolved by a process of negotiation between toxicologists and lawyers. ${ }^{37}$ It is, however, possible to use a national study of poisoning crimes to approach the question from a different angle, by exploring what constituted "normal" practice. Until the middle of the nineteenth century most defendants lacked counsel. Those who had lawyers could make little of the privilege if they had no money to pay for a second medical opinion. Hence, most poison trials did not involve experts ranged against one another. Indeed, the extent to which they can be said to have involved "experts" at all requires some unpacking.

The following analysis is based on a national survey of 535 poisoning crimes investigated in England (519) and Wales (16) from 1750 to 1914, compiled mainly from original assize depositions in the National Archives at Kew, and augmented by newspaper reports of trials and, where available, other primary and secondary published accounts. Although by no means an exhaustive survey of all poisoning crimes that occurred in this period, it is a representative sample of the types of incidents that coroners, magistrates and the police classified as (for the most part) deliberate felonies, and which were thus tried in the highest courts, the Old Bailey in London or the assize courts of each county. Cases of clearly suicidal and accidental death have not been included.

Table 1 lists the criminal charges that were brought against the suspected poisoners in the cases under study. The specifics varied slightly as statutes were introduced and repealed, but for the purposes of this study criminal poisonings have been taken to be those in which death or injury were caused by substances known to be toxic to human life. These substances were in the main those recognized today as poisons: arsenic and compounds of other heavy metals such as mercury and antimony; alkaloids such as strychnine; opiates and the mineral acids.

One factor that set poisonings apart from other crimes of violence was the potential difficulty in discovering that a crime had occurred at all. Although not a painless process, death by poison did not involve blood-letting, and so could in theory go completely unrecognized. There was also a real risk that it would be mistaken for natural disease, and it tended to happen behind closed doors, with no direct witnesses. There is now no way to calculate the "dark figure" of unrecorded crime, the number of criminal poisonings that were never pursued as such, nor even suspected. Those that were brought to light became the responsibility of local coroners (when the victim died) or magistrates (when the victim survived). ${ }^{38}$ The inquest remained the primary locus for the initiation of legal proceedings in cases of suspected poisoning until the second half of the nineteenth century, when the role played by the police began to transform the investigative process into one which looks familiar to the modern observer.

When a coroner wished to obtain a medical opinion, the usual method was to summon the practitioner who had attended the victim before death. If he refused, he could (like any

\footnotetext{
${ }^{37}$ Burney, 'Testing testimony', op. cit., note 2 above.

${ }^{38}$ The inadequacies of the coroners themselves undoubtedly contributed to the "dark figure". See
}

M B Emmerichs, 'Getting away with murder? Homicide and the coroners in nineteenth-century London', Soc. Sci. Hist., 2001, 25: 93-100. 


\section{Katherine D Watson}

Table 1

Selected Cases of Criminal Poisoning, England and Wales 1750-1914

\begin{tabular}{lc}
\hline Charge & Number of Cases \\
\hline Murder & 347 \\
Attempted murder & 77 \\
Manslaughter & 45 \\
Administering poison & 36 \\
Attempted poisoning & 12 \\
Other & 6 \\
Unknown & 6 \\
Poisoning & 3 \\
Case dismissed & 3 \\
Total & 535
\end{tabular}

other witness) be subpoenaed. If no one had treated the deceased, then the nearest medical man was selected, regardless of his qualifications for the task at hand. In the eighteenth century this was usually the parish surgeon, who could be compelled to attend even though he might not be paid. This practice did not change significantly after the Medical Witnesses Act of 1836 became law. ${ }^{39}$ This authorized coroners to ask a medical man (usually a surgeon, but occasionally an apothecary or physician) to attend an inquest and, if necessary, to carry out an autopsy and toxicological analysis; the maximum fee to be paid for these services was two guineas. Anyone who refused a coroner's summons could be fined, and inquest juries were free to request the opinion of a second doctor (and a second autopsy). ${ }^{40}$

Out of 535 cases in total, 367 or 68.6 per cent are known to have involved an autopsy or an "opening" of the victim's body, as specifically stated in the surviving records of each case-mainly (but not exclusively) those indicted as murder or manslaughter. This figure should be seen in relation to the fact that not all criminal poisonings resulted in death. And, it is at best an underestimate since, depending on the available sources of information, not all details of a case and the way in which it was investigated are known. Where there are no details about whether the body was opened, it has not been assumed. Nevertheless, this 68.6 per cent is a much higher proportion than previous studies suggest was the norm in cases of homicide during the second half of the eighteenth and much of the nineteenth century. ${ }^{41}$ In 392 cases of murder and manslaughter involving poison, 33 occurred before 1800 and in 70 per cent of them (23) an autopsy of sorts was conducted. From 1800 to 1835, out of 67 cases, 78 per cent (52) included an autopsy. Thereafter, of 292 cases at least 94 per cent (276) had an autopsy. Table 2 shows that the most common practice was to conduct both a post-mortem and an analysis. It should not be supposed that where no post-mortem was

\footnotetext{
${ }^{39}$ Attendance and Remuneration of Medical Witnesses at Coroners' Inquests Act (1836).

${ }^{40}$ Watson, op. cit., note 6 above, p. 165.

${ }^{41}$ Forbes, op. cit., note 2 above, p. 21 , shows that on average 46.3 per cent of Old Bailey homicide trials
}

(1729-1878) included an autopsy report. During the nineteenth century the rate of post-mortem examinations made during inquests increased, from roughly 20 per cent to over 50 per cent, see Burney, op. cit., note 17 above, p. 195, n. 25. 
Medical and Chemical Expertise in English Trials, 1750-1914

Table 2

Selected Cases of Murder and Manslaughter by Poison, England and Wales 1750-1914

\begin{tabular}{lc}
\hline Investigation & Number of Cases \\
\hline Autopsy and analysis & 288 \\
Autopsy, no analysis & 63 \\
Analysis, no autopsy & 7 \\
No autopsy or analysis & 34 \\
(of which, prior to 1836) & $(22)$ \\
Total & 392 \\
\hline
\end{tabular}

performed, no medical man was present. Many doctors, particularly during the earlier decades of this study, were prepared to make a diagnosis of poisoning on the basis of symptoms alone, and perhaps the feeding of suspect food or vomit to an animal.

Another factor that distinguished poisonings from other cases of homicide and violence against the person was the need for a chemical analysis to confirm a clinical diagnosis of poisoning and to identify the substance in any samples of food, stomach contents, vomit, faeces or medicine. Chemical analysis, varying in sophistication from rudimentary to highly complicated, is known to have been carried out in 387 of the 535 cases studied. We have the names of the analyst in all but seventeen of these: 160 of them appeared in one trial only, and 43 in more than one trial (together appearing in 210 trials-Table 3 lists these latter individuals), ${ }^{42}$ making a total of 203 different analysts throughout the period 1750 to 1914 . Neither autopsy nor analysis appears to have been done in 15.3 per cent of all the cases studied (82, about half before 1830 and half after, the majority not involving a death), but this is a maximum figure; further information about the cases in question would probably reduce it.

From the mid-eighteenth century until about 1836, the autopsy and analysis were often carried out by the same surgeon, many of whom were also apothecaries and thus had some experience with chemical analysis. But it was not uncommon to find that the surgeon, coroner or magistrate requested that an apothecary or professional chemist be brought in to carry out the analysis. Generally speaking, many medical witnesses were anything but expert: they were asked for their opinion merely because they happened to have been located conveniently near to the scene of a possible crime. Many were prepared to admit that they were out of their depth and needed the expertise of someone proficient in chemistry. Most of those who had the requisite training were medical men, or individuals who applied chemistry to entrepreneurial ends; there were then few academic chemists in the country. ${ }^{43}$ But in 1811 , one of these few was called upon to analyse samples taken in the

\footnotetext{
${ }^{42}$ The number of cases listed for each individual refers to entirely separate trials, with three exceptions: two of John Rayner's court appearances were in linked trials, as were those of Samuel Best Denton and Henry Nash.

${ }^{43} \mathrm{R}$ F Bud and G K Roberts, Science versus practice: chemistry in Victorian Britain, Manchester
}

University Press, 1984, pp. 47-69; F L Holmes, Eighteenth-century chemistry as an investigative enterprise, Berkeley, Office for History of Science and Technology, University of California, 1989, pp. 85-102. 


\section{Katherine D Watson}

case of Michael Whiting, a shopkeeper accused of attempting to poison his two brothers-inlaw. The Reverend Francis John Hyde Wollaston, Jacksonian Professor of Chemistry at Cambridge, was called in, almost certainly because of his physical proximity to the crime, which occurred at Ely. A man of some means and status, Whiting had a lawyer, but he was convicted and executed. ${ }^{44}$ Although Wollaston was certainly an expert chemist, and had extensive experimental skill, we can hardly say that he, or Mark Edward Poskitt or any of the others who testified in poison trials around that time, had any particular expertise when it came to cases of poisoning. They were expert witnesses by definition only: although they conducted experiments, and often succeeded in isolating and identifying the mineral poisons typically employed for homicidal purposes, they were usually operating in a completely novel environment. If a surgeon was then prepared to state that the poison found had killed the victim, coroners, magistrates and juries tended to believe them. Since defence counsel was so rare, there was usually no one to attempt to rebut their claims, and judges were satisfied when the balance of all the evidence indicated that guilt had been proved beyond reasonable doubt. Trials for murder by poison tended to rely heavily on circumstantial evidence.

\section{The Formalization of the Role of the Expert Witness in Poisoning Cases}

The profile and status of scientific witnesses in poisoning cases began to change in the early 1830s, the result of several factors which together fostered the development of a small number of recognized experts, each of whom possessed a vast amount of knowledge about the science of poisons - toxicology-and, importantly, had the ability to present it in a courtroom clearly and succinctly. At the same time, professional opportunities for chemists began to grow, leading to the creation of a pool of academic chemists who could be asked to conduct medico-legal analyses.

In 1831 the Society of Apothecaries decided that candidates for their diploma should attend lectures in medical jurisprudence, and Guy's Hospital established a lectureship in medical jurisprudence the same year. The first holder of the post was a young surgeon named Alfred Swaine Taylor (1806-1880), who lectured on both forensic toxicology and, later, chemistry. During the course of a career that spanned over forty years, Taylor contributed more than any other individual to the professional establishment of forensic toxicology in England, due mainly to his ability to bring scientific evidence into line with the demands of the law in regard to what constituted proof of poisoning. His textbooks influenced many generations of young scientists, even though Taylor himself was not an outstanding analyst. ${ }^{45}$ But he was not the only toxicologist to emerge at this time. In Bristol, William Herapath (1796-1868) was largely self-taught in chemistry and toxicology, developing so great a local reputation that he began to be consulted as a professional analyst and became one of the founders of the Bristol Medical School, which opened in

\footnotetext{
${ }^{44}$ The trial of Michael Whiting, for administering poison to George and Joseph Langman, Cambridge, 1812.

${ }^{45}$ Coley, 'Alfred Swaine Taylor', op. cit., note 1 above, pp. 413, 426. Taylor recognized that samples
}

had to be free from contamination, the poison had to be identified in the corpse as well as in food taken by the victim, and the quantitative amount of poison found had to be related to the fatal dose. 


\section{Medical and Chemical Expertise in English Trials, 1750-1914}

1832 and at which he lectured on chemistry and toxicology until 1867. His appearance as a prosecution witness at the 1835 trial of Mary Ann Burdock, in which he exhumed a body that had been buried for fourteen months and successfully demonstrated the presence of arsenic in it, marked a first in English forensic analysis and led to a career on the witness stand that was second only to Taylor's. Unlike Taylor, however, he published very little.

In 1833 the trial of a dissolute youth for the poisoning of his grandfather led directly to the development of the famous Marsh test for arsenic. When John Bodle came under suspicion of murder at Plumstead, in Kent, in November 1833, the coroner tried to enlist the services of the nearest competent chemist, Michael Faraday, who was chemical lecturer at the Royal Military Academy in Woolwich. But Faraday could not take on the case, so it passed to his assistant, James Marsh (1794-1846). Marsh was able to show that arsenic was present in the coffee that the dead man had drunk, but was unable to demonstrate its presence in the stomach contents. Although the jury accepted that the victim had died from poison, they had doubts that Bodle was directly responsible, and acquitted him. ${ }^{46}$ Inspired by the ambiguity of this medico-legal experience, Marsh set out to develop a test for arsenic that would detect even the tiniest amounts in organic samples, and by 1836 he had succeeded. ${ }^{47}$

Because very delicate, the Marsh test required a great deal of skill on the part of the person who performed it, and was thus subject to errors and misleading results in the hands of the inexperienced. Moreover, each test took several hours to perform. Although its merits were debated, legal records show that it was in use by provincial medical practitioners and chemists in England and Wales during the early 1840s. ${ }^{48}$ There was, however, a clear need for a simpler but similarly sensitive test, and in 1841 the German chemist Hugo Reinsch published a description of a method whereby metallic arsenic was deposited on copper foil from hydrochloric acid solutions. ${ }^{49}$ The test was quicker than Marsh's, since it could be applied to a liquid containing organic matter. ${ }^{50}$

The existence of two reliable chemical tests for arsenic, the main poison used in criminal cases, would not have made much difference to the detection and prosecution of poisoning crimes had there not been a number of skilled analysts capable of using the tests accurately and confidently. Among the cases now under study, 43 analysts, many of whom were active during the middle of the nineteenth century, appeared at least twice in a poison trial (Table 3). Not only were they located all over the country, most especially in urban centres, they were based mainly in academic institutions, primarily medical schools and chemical

\footnotetext{
${ }^{46} \mathrm{~W} \mathrm{~T}$ Vincent, The records of the Woolwich District, vol. 1, Woolwich, J P Jackson, 1888, pp. 534-42; K D Watson, 'Criminal poisoning in England and the origins of the Marsh test for arsenic', in J R Bertomeu-Sánchez and A Nieto-Galan (eds), Chemistry, medicine and crime: Mateu J B Orfila (1787-1853) and his times, Canton, MA, Science History Publications, 2006, pp. 183-206.

${ }^{47} \mathrm{~J}$ Marsh, 'Account of a method of separating small quantities of arsenic from substances with which it may be mixed', Edinburgh New Philosophical Journal, 1836, 21: 229-36.
}

\footnotetext{
${ }^{48}$ See, for example, the cases of Robert and Ann Sandys, and Ann Edge (Cheshire, 1841); Hannah Roberts (Flintshire, 1842); Sarah Dazley (Bedfordshire, 1843); Betty Eccles (Lancashire, 1843).

${ }^{49} \mathrm{H}$ Reinsch, 'On the action of metallic copper on solutions of certain metals, particularly with reference to the detection of arsenic', Phil. Mag., 1841, 19: 480-3. This article was first published earlier in the same year in the Journal für praktische Chemie.

${ }^{50}$ For more on Marsh, Reinsch and nineteenthcentury chemical tests for arsenic, see W A Campbell, 'Some landmarks in the history of arsenic testing', Chemistry in Britain, 1965, 1: 198-202.
} 


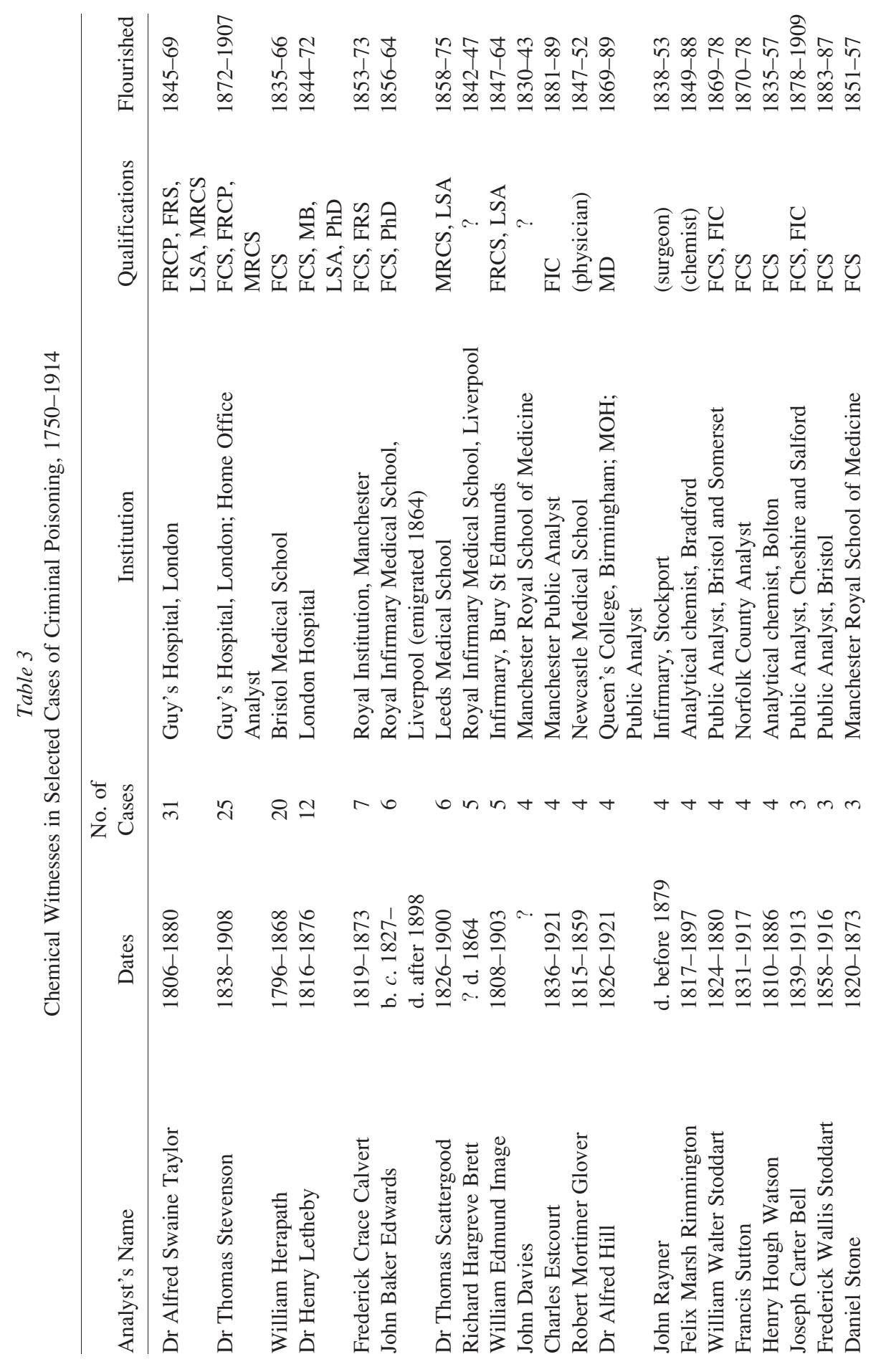




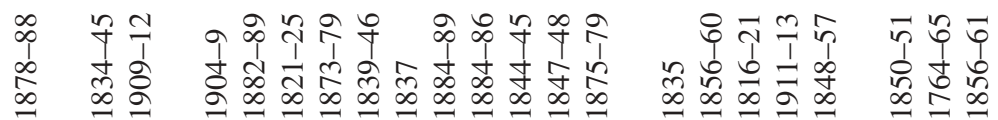

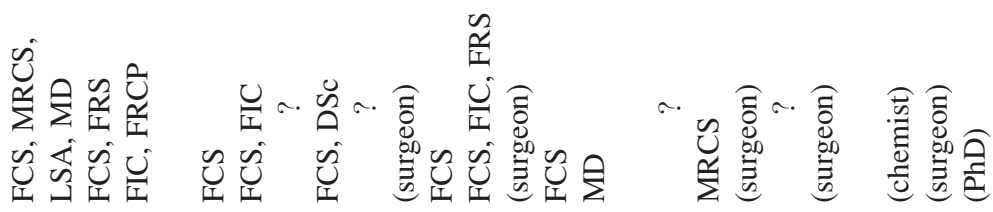

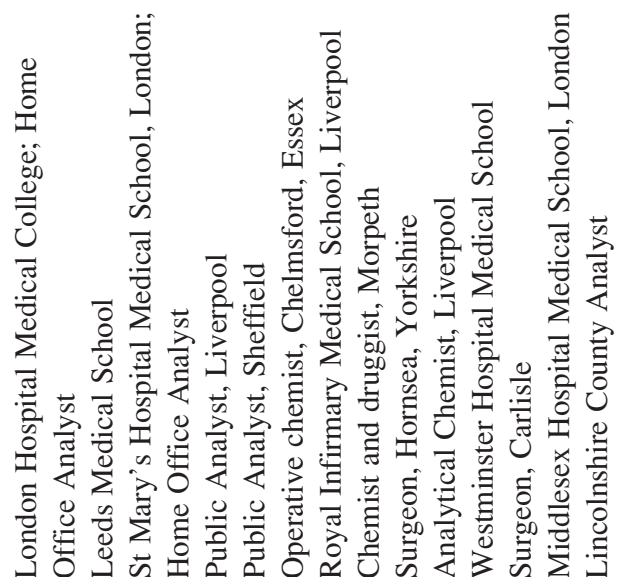

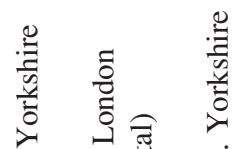

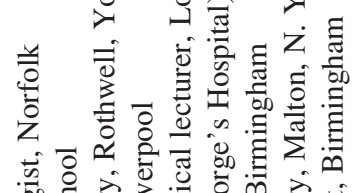

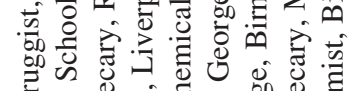

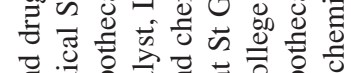

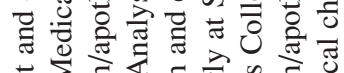

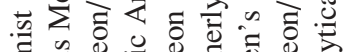

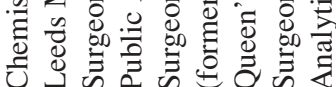

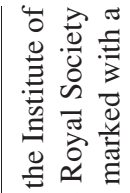

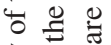

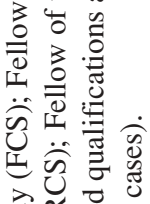

党 $\bar{z}$

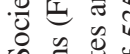

है

.ֶ.

ठ

$\stackrel{0}{0} \ddot{0}$

记苍志

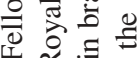

远焉

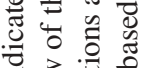

寻寻

흘 율

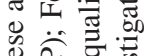

宅

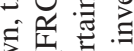

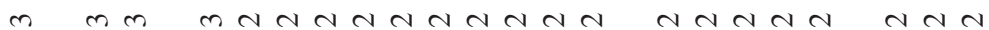

运远

音.

言

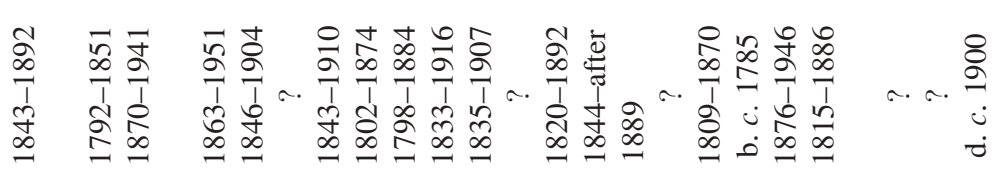

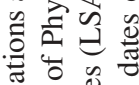

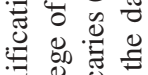

형웡

离范交离

宓金苍

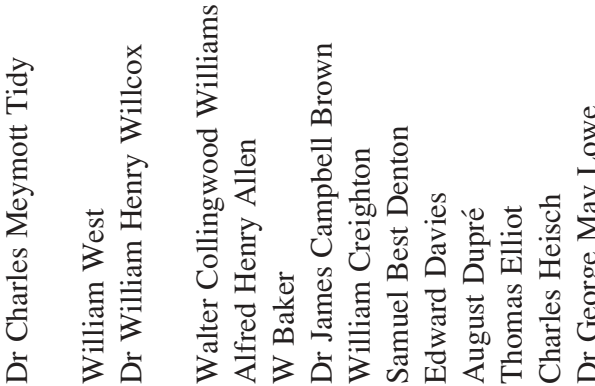

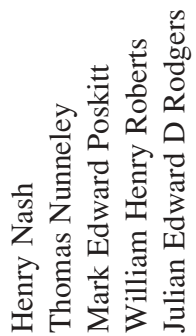

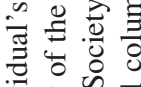

:

寻芒

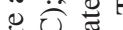

远记

过光

$\approx 3$

인 푼

0.00

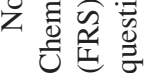




\section{Katherine D Watson}

laboratories. Although Taylor was the most well known, he had rivals in London and the provinces, where regional experts tended to dominate all but the most notorious cases. The coming of the railways facilitated cooperation between professionals based in different cities, and the need for their knowledge began to grow as the poverty of the 1830s and 1840 s led to increased numbers of criminal poisonings. ${ }^{51}$

So, by the 1840 s the typical scenario was this. The post-mortem was usually performed by the first doctor on the scene. It was his responsibility to obtain samples and remove organs, and to give them (or to send via post or police officer) to a trained chemist for analysis. It was not necessary for the analysts to be present at the autopsy: unless they had medical credentials, they were not qualified to state cause of death, merely the quantity and nature of the poison found. Although most were prepared to affirm that what they had detected was or was not a fatal dose, their testimony had to be linked with that of a doctor. For their part, doctors frequently stated that they could not be sure of the cause of death without a chemical analysis, and many were forced to revise their opinions in the wake of an analysis. The two types of evidence had to work together. Those analysts who had both chemical and medical training were clearly best placed to make a strong presentation in court. As they grew in forensic experience, some chemists tended to form opinions that strayed into medical territory, ${ }^{52}$ but this was a feature mainly of the mid-nineteenth century.

Despite the fact that medical testimony became more and more commonplace, its quality was often hit and miss. Some practitioners had little idea of what to look for during an autopsy. An unknown number of deaths were wrongly attributed to suicide and accident, and some murders (including many poisonings) were never detected. ${ }^{53}$ Police surgeons and hospital pathologists began to take on a greater share of the burden of autopsy during the late nineteenth century, but feature in very few of the cases currently under study. ${ }^{54}$ By contrast, the quality of the chemical evidence, and the professional standing of the men who provided it, continued to grow throughout the century.

Only Taylor was regularly consulted in cases that occurred outside London, where he was based. Herapath was mainly associated with cases in the west of England, Henry Letheby with London. The others, some of whom had business and academic interests that made them known around the country, were called upon to do forensic chemical analyses only in cases that occurred in or near their home towns. Many were chemistry lecturers in

\footnotetext{
${ }^{51}$ On the relationship between poverty and poisoning in the $1830 \mathrm{~s}$ and $1840 \mathrm{~s}$, see Watson, op. cit., note 6 above, pp. 58, 81-91, 206-7.

${ }^{52}$ See, for example, Herapath's testimony in these cases: PRO, ASSI 72/1 (Breconshire), 'July 1849Regina v. Margaret Michael'; PRO, ASSI 72/1 (Pembrokeshire), 'Spring assizes 1863-Regina v. Jane Thomas and Anne Thomas'. Calvert drew some medical conclusions in an 1866 case, stating that the amount of prussic acid taken by the victim would not be fatal to a healthy person (PRO, PL 27/17, box 1 (Lancashire), 'Lancaster summer assizes, 1866-The Queen v. Henry Hargreaves'), but in 1872 refused to speculate on whether a poison administered some months before death would account for the
}

internal appearances found at autopsy (PRO, ASSI 65/8 (Cheshire), '24 Oct. 1872-Regina v. Edwin Eastwood'). Watson, ibid., pp. 169-70.

${ }^{53}$ Havard, op. cit., note 28 above, p. 64, and Emmerichs, op. cit., note 38 above, pp. 94-7. G Robb, 'Circe in crinoline: domestic poisonings in Victorian England', J. Fam. Hist., 1997, 22: 176-90, pp. 179-80, $182,185-6$, notes contemporary unease about undetected poisonings.

${ }^{54}$ Careers in pathology scarcely existed before the 1880s: see W D Foster, Pathology as a profession in Great Britain and the early history of the Royal College of Pathologists, London, Royal College of Pathologists, 1982, pp. 1-18. 


\section{Medical and Chemical Expertise in English Trials, 1750-1914}

teaching institutions, usually medical schools; others taught toxicology or forensic medicine. These academic positions-which bore an attendant social status and intellectual authority-automatically made the men who held them an obvious source of expertise to coroners and police whenever cases of suspected poisoning emerged. It is unsurprising that most were located in large urban centres, the first cities outside London where medical schools and chemical laboratories were established. Between 1824 and 1858 eleven provincial medical schools were set up, one result being that the professors of chemistry (most of whom had medical degrees) were liable to be called in locally; through experience, they became expert witnesses. In London, where nine teaching hospitals had been established by 1850 , professors from all were liable to be called upon, though Taylor and Letheby were the clear favourites with legal officials. Unlike many of their colleagues, they relished the opportunity to enter a witness box, where their calm manner, lucid explanations, sharp memories and critical minds made them superb scientific witnesses. ${ }^{55}$

As Taylor's fame grew, he began to accept samples for analysis from all over the country, and it was his insistence on receiving a fee that adequately reflected the expenses incurred that set a standard. The law of 1836 had considered only the cost of analysing the contents of the stomach and intestines, for a fee of one guinea, but in practice several different organs and samples had to be analysed. This was not a cheap process. In the $1840 \mathrm{~s}$ Letheby estimated the cost of a single arsenic analysis to be about $£ 1$ in materials and two days of his time, for a case that required him to make six analyses. ${ }^{56}$ Around the same time, Herapath charged the county of Monmouthshire fifteen guineas for a series of analyses that took him three days to complete. ${ }^{57}$ Taylor's fee was then about two guineas per sample, including materials and time; it was more if he had to consult with a client or travel to give evidence. ${ }^{58}$ Given the financial constraints that coroners had to endure, many must have balked at the thought of the potential cost when faced with cases of poisoning. ${ }^{59}$ But those who seemed unwilling to hire the best analysts were sometimes persuaded to do so by the medical men involved in the case, or by public opinion. When Jane Wooler died in suspicious circumstances in 1855, the coroner claimed that the necessary analysis could be done as well and more cheaply in Newcastle as in London, but was at last persuaded to call in Taylor in support of the Newcastle analyst, Thomas Richardson. ${ }^{60}$ Six years earlier, jurors at an inquest in Bath, dissatisfied by the coroner's failure to appreciate the gravity of the case, had pressed him to send for the surgeon and analyst of their choice. In sticking "hard and fast" to their demand to involve William Herapath, the jurors exercised "more discernment" than the coroner: Herapath's analysis and

\footnotetext{
${ }^{55}$ Watson, op. cit., note 6 above, pp. 167-8.

${ }^{56}$ The Times, 13 Nov. 1847, p. $8 \mathrm{e}$.

${ }^{57}$ PRO, ASSI 6/5 (Monmouthshire), 'Lent assizes 1848-Regina v. Mary Howells and James Price'.

58 'Action for recovery of fees for chemical analyses; implied contracts', Pharm. J., 1851-52, 11: $185-8$.

${ }^{59}$ Howard Taylor has suggested that bureaucratic and political control of crime statistics, linked to the cost of prosecuting murder cases (poisonings being
}

particularly expensive), led to an artificially maintained average annual number of murders. This meant that coroners and police, to stay within budget, often took no action in cases that might have been murders. See $\mathrm{H}$ Taylor, 'Rationing crime: the political economy of criminal statistics since the 1850 s', Econ. Hist. Rev., 1998, 51: 569-90, pp. 583-8.

${ }^{60}$ Great Burdon slow poisoning case, Darlington, Robert Swales, 1855, p. 8. 


\section{Katherine D Watson}

testimony proved that what had at first been assumed to be a natural death was in fact a case of criminal poisoning. ${ }^{61}$

In contrast to the academics, around mid-century there were a small number of hospitalbased surgeons whose chemical skills were evidently so reliable that they became local experts. Two important examples here are John Rayner of Stockport, and William Edmund Image of Bury St Edmunds, both of whom provided testimony at notable murder trials. ${ }^{62}$ Their training allowed them to do both autopsy and analysis, and their courtroom performance must have impressed legal officials. They continued the eighteenth-century practice of local surgeons or surgeon-apothecaries performing both procedures. There were also a few independent analysts, men who made a career as consulting chemists (for example, $\mathrm{H}$ $\mathrm{H}$ Watson of Bolton and F M Rimmington of Bradford). At no point were any of these individuals limited in their interests or practice to toxicological analysis.

The wide-ranging scope of the forensic work undertaken by nineteenth-century medicolegal experts is exemplified by the career of Thomas Scattergood (1826-1900), a general practitioner who became a consulting surgeon and lecturer in forensic medicine and toxicology at the medical school in Leeds. From 1856 to 1897 he kept a record of his medico-legal work, and this describes over 300 cases, including many poisonings (of both humans and animals), but also food and drug adulteration, pollution, cases of bestiality, alleged rape and head injuries. ${ }^{63}$

By the last quarter of the nineteenth century, the list of expert witnesses who regularly appeared in cases of poisoning was dominated by the names of public analysts. This resulted from a process that began in the 1850s, stimulated by Thomas Wakley, medical reformer and editor of the influential journal the Lancet. Under the aegis of the journal, Wakley established an analytical sanitary commission to investigate food adulteration in London, and its various reports were published in 1855. As a direct consequence, the government appointed a parliamentary committee, its report resulting in the passing of the Adulteration Act of 1860. This permitted the counties and the districts of London to appoint analysts to be responsible for ensuring food standards and the purity of medicines; but it was not compulsory. To remedy its defects and extend the law's provisions to all boroughs, it was revised in 1872. Two years later the Society of Public Analysts was founded, including among its first members the public analysts of Sheffield, Manchester, Bradford, Cheltenham and several districts of London. ${ }^{64}$ Many of these men soon appeared as expert witnesses at inquests and poison trials, while others had been doing so long before taking up these formal posts. Many of the earliest members of the society were as interested in food, water and drug analysis as in toxicology — and vice versa. Furthermore, the Public

\footnotetext{
${ }^{61}$ Watson, op. cit., note 6 above, pp. 170-1; The Times, 2 May 1849, p. 8e (this was the case of Charlotte Harris).

${ }^{62}$ Image testified against the locally notorious Catherine Foster (1847) and Mary Emily Cage (1851), both of whom were executed, and also William Rollinson (1852), who was reprieved from execution on account of his great age. Rayner witnessed the beginning of the mid-century trend in insurance-related child poisonings during his work on the cases of Robert Standring (1839) and
}

Robert Sandys (1841), and continued it in the trial of Honor Gibbons and her mother Bridget Gerraty (1853).

${ }^{63}$ Green, op. cit., note 1 above; University of Leeds, Brotherton Library, MS 534/1-3, 'Thomas Scattergood, case notes'.

${ }^{64}$ B Dyer and C A Mitchell, The Society of Public Analysts and other Analytical Chemists: some reminiscences of its first fifty years; and a review of its activities, Cambridge, published for The Society by W Heffer \& Sons, 1932, pp. 1-3. 


\section{Medical and Chemical Expertise in English Trials, 1750-1914}

Health Act of 1875 required the appointment of a medical officer of health to every district in England and Wales, codifying sanitary legislation that had been developing since the cholera epidemic of 1848 . These men were often also public analysts, while many of the analysts had medical training; by 1874 there were seventy-seven public analysts holding 110 appointments. ${ }^{65}$ Those who filled these new public positions quickly became sources of expertise to other branches of the state apparatus, including coroners and the police. ${ }^{66}$

One public analyst above all made a lasting mark on the science of toxicology and the practice of forensic medicine. Thomas Stevenson (1838-1908) held qualifications in chemistry, medicine and surgery when he took up a junior post at Guy's Hospital in 1864; he succeeded to Taylor's lectureships in the 1870s. In 1878 he became public analyst for St Pancras and the counties of Surrey and Bedfordshire. But he was best known for the post that was to involve him in nearly all the most notorious poisoning cases of the next thirty-five years: in 1872 he was appointed Scientific Analyst to the Home Office, becoming Senior Scientific Analyst nine years later. ${ }^{67}$ This created a formal relationship with the state that his eminent predecessor did not have. ${ }^{68}$ Although Stevenson was not paid an annual retaining fee until $1899,{ }^{69}$ it was the Home Office's intention that all analyses in criminal cases should be entrusted either to him or to his junior, ${ }^{70}$ which meant that his services were, in practice if not in theory, available only to the state. His position as a skilled and trusted servant of the nation led to his appearance in every case that seemed especially complex, sometimes as a second opinion but usually as the prosecution's principal scientific witness.

\section{Conclusion}

Stevenson's appointment as Home Office Analyst marked the beginning of the end of a long period during which, in England and Wales, the expertise of the chemical witnesses in cases of criminal poisoning had often surpassed that of the medical witnesses, and inaugurated an era when the two roles became increasingly combined in the person of one medico-toxicological expert working directly for the state. Home Office records indicate that the position of Official Analyst was originally intended for men who held both medical and chemical qualifications, and in 1904 Stevenson pointed out that the holder of the post must be "primarily a good analytical chemist, and also a fair pathologist". 71

Stimulated by intense specialization in medicine and science, however, the number of individuals who fulfilled these criteria began to decrease around the turn of the twentieth

${ }^{65}$ Pharm. J., 3rd series, 1874-75, 5: 121-32.

${ }^{66}$ Watson, op. cit., note 6 above, pp. 171-2.

${ }^{67}$ R O Myers, 'Famous forensic scientists, 5: Sir Thomas Stevenson (1838-1908)', Medicine, Science and the Law, 1962, 2: 165-8; C E G, 'Thomas Stevenson', J. Chem. Soc., 1909, 95: 221315; S B A, 'Sir Thomas Stevenson, MD, FRCP', Trans. Med.-Leg. Soc., 1907-08, 5: 186-8; Streatham News, 1 Aug. 1908 , p. 8.

${ }^{68}$ That Taylor had a relationship with the Home Office is evident from a comment made years after his death, when an official referred to "the days when Dr A S Taylor was the Home Office Analyst". See PRO, HO 45/10258/X67417, Memo, 12 May 1898.
${ }^{69}$ PRO, HO 45/10258/X67417, memos of December 1898 and August 1899. Stevenson was to receive $£ 150$, and his junior (Arthur Luff) $£ 75$.

${ }^{70} \mathrm{PRO}, \mathrm{HO} 45 / 10258 / \mathrm{X} 67417$, letter from A F O Liddell to T Stevenson, 8 May 1882 , ref. A15734/6.

${ }^{71} \mathrm{PRO}, \mathrm{HO} 45 / 10258 / \mathrm{X} 67417$, letter from T Stevenson to M D Chalmers, 9 May 1904. His junior colleagues Charles Tidy (in post 1882-92) and Arthur Luff (1892-1904) were qualified in both medicine and chemistry, though John Webster (who worked as a Home Office Analyst from 1900 until his death in 1927) held qualifications solely in chemistry. 


\section{Katherine D Watson}

century. The role of public analyst increasingly demanded the skills of a trained chemist, and gradually fewer medical men and more chemists were appointed. In 1900 the Local Government Board decreed that all appointees had to supply evidence of proficiency in analytical chemistry, therapeutics and microscopy, and by 1929 a medical diploma was no longer considered satisfactory proof of chemical aptitude. By the late 1930s the offices of public analyst and medical officer of health had become quite separate. ${ }^{72}$ Meanwhile, career opportunities in chemistry flourished, as growth in industry and academia led to the creation of more and more specialist disciplines, qualifications, societies and professional distinctions. $^{73}$

Thus, although the pool of forensic expertise had expanded enormously by the end of the nineteenth century, in homicide cases the number of expert witnesses had actually contracted: a few senior figures dominated the forensic landscape, much as they do today. Poisoning cases had become primarily the province of the Home Office Analysts, and the best pathologists also became servants of the state. Most carried out mainly public health work, but in London, Augustus Pepper of St Mary's Hospital became Home Office Pathologist in the 1890s. In 1908 the Department of Public Prosecutions was founded, under Home Office control, relying for medical advice on the Home Office Analysts and Pathologists. The latter, all of whom were on the staff of St Mary's, dominated the medicolegal scene until the 1940s, the most famous being the renowned "medical detectives" William Willcox (1870-1941), who held the post from 1904-19 and was both analyst and pathologist, and Bernard Spilsbury (1877-1947), a pathologist appointed in $1908 .{ }^{74}$ By the end of his career Spilsbury had become so influential that his mere reported interest in a case was said to have a "very substantial psychological effect on the minds of the jury". 75

By the early twentieth century, then, the best toxicologists and pathologists had either become de facto employees of the state or were, because of their professional eminence, likely to be called upon as obvious consultants in forensic matters. Add to this the fact that access to lawyers had become an entrenched right, and it becomes clear that the professionalization of forensic medicine and toxicology may well have been a factor in a pattern of change in criminal cases comparable to that of the rise of the legal profession in civil cases. The result being that the fact-finding aims of a trial will sometimes be overwhelmed by the potential for conflict between expert witnesses acting for the opposing parties; and the reliance of juries on expert credibility and reputation rather than on a close scrutiny of the content of their evidence. ${ }^{76}$ Although much more legal-historical work is required to explore and define the overall scope of this transition, ${ }^{77}$ by identifying how forensic toxicological expertise and its practitioners changed over the course of the eighteenth and nineteenth centuries this article has perhaps also contributed to wider discussions about expert testimony and its role in an adversarial legal system.

\footnotetext{
${ }^{72} \mathrm{C}$ A Mitchell, Forensic chemistry in the criminal courts, London, Institute of Chemistry, 1938, pp. 13-14.

${ }^{73}$ Bud and Roberts, op. cit., note 43 above, pp. 150-63.

${ }^{74}$ Jones, op. cit., note 15 above, pp. 73-95; P H A Willcox, The detective-physician: the life and work of Sir William Willcox, London, William
}

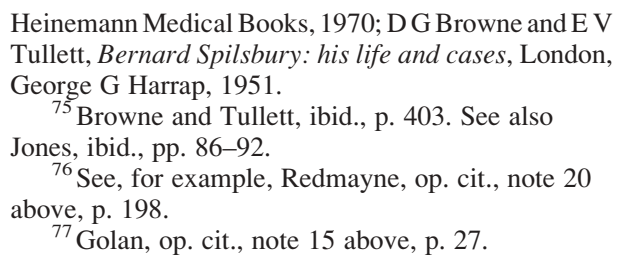

Heinemann Medical Books, 1970; D G Browne and E V Tullett, Bernard Spilsbury: his life and cases, London, George G Harrap, 1951.

${ }^{75}$ Browne and Tullett, ibid., p. 403. See also Jones, ibid., pp. 86-92.

${ }^{76}$ See, for example, Redmayne, op. cit., note 20 above, p. 198.

${ }^{77}$ Golan, op. cit., note 15 above, p. 27. 